\title{
2,4-DICHLOROPHENOXYACETIC ACID AS AN ALTERNATIVE AUXIN FOR ROOTING OF VINE ROOTSTOCK CUTTINGS ${ }^{1}$
}

\author{
MAURO BRASIL DIAS TOFANELLI², PYTÁGORAS LEAL FREITAS ${ }^{3}$, GIULIANO ELIAS PEREIRA ${ }^{4}$
}

\begin{abstract}
Viticulture is an important agricultural activity in semiarid northeastern Brazil, and the quality and ease of vine propagation are very important in this context. This study evaluated the use of 2,4-dichlorophenoxyacetic acid $(2,4-D)$ as an alternative to indolebutyric acid (IBA) in the rooting of vine rootstock cuttings. The trial was conducted at the Universidade Federal de Sergipe (São Cristóvão-SE) between January and March 2010 with cuttings of the rootstocks of 'IAC-766', 'IAC-572', and 'Paulsen 1103' treated with 2,4-D or IBA applied at concentrations of $0,1000,2000$, or $3000 \mathrm{mg} \cdot \mathrm{L}^{-1}$ for $5 \mathrm{~s}$ and planted in a field on washed sand. At 56 days after planting, the percentages of rooted, sprouted, callused, and dead cuttings were evaluated, and also the average number and length of the rooted cuttings. The results showed that 2,4-D was not superior to IBA in the characteristics wanted for the rooting process of the vine rootstock cuttings. The vine rootstocks showed potential for propagation by cutting without auxin application. It was observed that the high concentrations were the worst for the rooting of the cuttings. Index terms: Vitis, propagation, semiarid, cuttings, auxin, 2,4-D.
\end{abstract}

\section{ÁCIDO 2,4-DICLOROFENOXIACÉTICO COMO AUXINA ALTERNATIVA NO ENRAIZAMENTO DE ESTACAS DE PORTA-ENXERTOS DE VIDEIRA}

RESUMO - A viticultura é uma atividade agrícola marcante no semiárido do Nordeste brasileiro, sendo a qualidade e a facilidade de propagação das videiras importante neste contexto. O objetivo deste trabalho foi avaliar o uso do ácido 2,4-Diclorofenoxiacético (2,4-D) como forma alternativa para o ácido indolilbutírico (AIB) no enraizamento de estacas de porta-enxertos de videira. Para isso, foi conduzido um experimento à Universidade Federal de Sergipe (São Cristóvão-SE), de janeiro a março de 2010, com estacas de porta-enxertos 'IAC-766', 'IAC-572' e 'Paulsen 1103' tratadas com 2,4-D e AIB, nas concentrações de 0; 1.000; 2.000 e $3.000 \mathrm{mg} \mathrm{L}^{-1}$, por 5 segundos, e, posteriormente, plantadas em canteiros com areia lavada. Aos 56 dias após o plantio, avaliaram-se as porcentagens de estacas enraizadas, brotadas, com calo e mortas, número médio de raízes e comprimento médio de raízes das estacas enraizadas. Os resultados demonstraram que o 2,4-D não supera o efeito do AIB quanto às características necessárias para o processo de enraizamento das estacas dos porta-enxertos de videira. Os porta-enxertos de videira demonstraram potencial de propagação por estaquia de ramos sem a necessidade de aplicação de auxina. Observou-se que as auxinas em concentrações mais elevadas tornam-se prejudiciais ao enraizamento das estacas. Termos para indexação: Vitis, propagação, semiárido, estaquia, auxina, 2,4-D.

'(Trabalho 266-13). Recebido em 05-08-2013. Aceito para publicação em: 12-06-2014. Apoio: DFF/SCA/UFPR

${ }^{2}$ Engenheiro Agrônomo, Doutor, Professor, Departamento de Fitotecnia e Fitossanitarismo, Setor de Ciências Agrárias, Universidade Federal do Paraná, Rua dos Funcionários, n 1540, Cabral, 80035-050. Curitiba-PR. Email: mbrasildt@ufpr.br.

${ }^{3}$ Engenheiro Agrônomo, Egresso, Departamento de Engenharia Agronômica, Universidade Federal de Sergipe, 49100-000. São Cristóvão-SE. E-mail: pyttyfreitas@hotmail.com.

${ }^{4}$ Engenheiro Agrônomo, Doutor, Pesquisador, Embrapa Uva e Vinho/Semiárido, BR 428, Km 152 Zona Rural, 56302-970. PetrolinaPE. Email: giuliano.pereira@embrapa.br. 


\section{INTRODUCTION}

The traditional vitiviniculture in Brazil is located in the states of Rio Grande do Sul, São Paulo, Pernambuco, Paraná, Santa Catarina, Bahia, and Minas Gerais. In other regions, however, it is not common, even when there are favorable climatic conditions for the cultivation of Vitis spp. vines. For example, the statistics of the Brazilian government do not list grape production as occurring in the state of Sergipe in northeastern Brazil (IBGE, 2013).

There are many issues to consider when deciding whether to increase the area used to grow a certain crop. For fruit production, the propagation of the species is expensive and arduous; however, it is crucial for the success of the plants (HARTMANN et al., 2010), because most fruits are perennial cultures, where the new plants are introduced once to be grown commercially for many years after. In this way, the development of new methodologies of propagation to decrease costs and simplify and/or improve fruit tree production can increase fruit-growing areas.

Vines have evolved for a long time and have generated diverse species adapted to many different climate and soil conditions and with resistance to pests and diseases. Vineyards are always formed using grafted plants, with the rootstock coming from cuttings, and the cultivars IAC-572 (Jales), IAC-766 (Tropical), and Paulsen 1103 are well adapted and recommended for this use in semiarid northeastern Brazil (LEÃO et al., 2009).

Most of the rootstocks used in Brazilian viticulture easily root in the temperate zones of the south and southeast where the climate conditions are favorable. However, the climatic conditions of semiarid areas are very different from the traditional winegrowing regions of the country, and it is sometimes necessary to carefully get good rooting by using irrigation or greenhouses with controlled humidity (ALBUQUERQUE; ALBUQUERQUE, 1981), and little information about the best methods is known.

According to Smart et al. (2003), vegetative propagation is the most appropriate method to disseminate vine cultivars around the world. However, for the introduction and establishment of vine plants in a specific area, it is very important to determine the influence of the treatments used on the rooting of cuttings from different rootstocks because each can respond differently in specific climate and soil conditions. Hartmann et al. (2010) showed that the capacity of a cutting to root depends on internal factors, like the physiological conditions of the matrices, type of cutting, age of the plant, and intrinsic hormonal balance, and external factors, like temperature, light, humidity, substrate, and conditioning. The adequate control of these will increase the probability of the successful production of plants from cuttings. Synthetic plant growth regulators of the auxin group have been used to increase the rooting percentage of rootstock cuttings.

The response of the cuttings to exogenous auxin application depends on the plant species and the concentration of the substance in the tissue, and the composition (type) of the synthetic auxins is important in this process (HARTMANN et al., 2010). Other important factors in this context are the cultivar of the plant species, concentration of the auxin solution, duration of the treatment, and method of application (CAMPAGNOLO; PIO, 2012; PEÑA et al., 2012; VIGNOLO et al., 2012).

Auxin products, such as indolebutyric acid (IBA), which is one of the most recommended substances for promoting the rooting of plant bunches propagated by cuttings (VIGNOLO et al., 2012; LONE et al., 2010; DENEGA et al., 2009), are not always easily available for producers at affordable prices. Many products made from 2,4-dichlorophenoxyacetic acid $(2,4-D)$, an auxin, can be easily found commercially, but they are registered as herbicides (MAPA, 2013). If they could be sold as plant growth regulators based on technical evidence, it would increase the likelihood of the use of this kind of auxin by plant producers. According to Oliveira et al. (2010), IBA has the advantages of being photostable, not attacked by biological actions, and less toxic in many concentrations when applied in cuttings, while 2,4-D presents high rooting activity but also has high toxicity for the cuttings, and IBA is the product preferred for the hormonal treatment of cuttings. However, 2,4-D is one of the main synthetic plant regulators and presents analogous activity to auxins in the promotion of lateral rooting and inhibition of root stretching (WOODWARD; BARTEL, 2005; SIMON; PETRÁSEK, 2011).

Because 2,4-D has high phytotoxicity, it is possible that it should not be used as a commercial rooting substance, but there is a lack of studies on this, so the effects of this compound on the rooting of vine cuttings should be tested. Thus, the aim of this study was to evaluate the effects of the application of IBA and 2,4-D on the rooting of vine rootstock cuttings in the tropical semiarid conditions of northeastern Brazil.

\section{MATERIALS AND METHODS}

The trial was conducted in the Departamento de Engenharia Agronômica (DEA) of the Universidade Federal de Sergipe (UFS), located in São Cristóvão, Sergipe, from January to March of 2010.

The rootstock cuttings were obtained from woody bunches collected in the vineyard at the Embrapa 
Semiárido on 25 January 2010. The cuttings were prepared by eliminating the leaves from $40 \mathrm{~cm}$ of length with at least two buds and making a horizontal cut at the base and a bevel cut at the apex. After the harvest and preparation of the cuttings, they were immersed in water and placed in plastic sacks for preservation during their transport from Petrolina-PE to São Cristóvão-SE (about $460 \mathrm{~km}$ ). They were attached in bundles and planted in washed sand in a shaded place (under a canopy of trees) and irrigated daily until the application of the experimental treatments one week later. Cuttings from three vine rootstocks, IAC-766 - 'Campinas' [ $(V$. riparia $\times V$. rupestris $\times V$. cordifolia $-106-8 \mathrm{Mgt} \times V$. caribea], IAC-572 - 'Jales' $[$ V. caribea $\times($ V. riparia $\times V$. rupestris - 101-14)], and Paulsen 1103 (V. beralandieri $\times$ V.rupestris), were treated with one of two kinds of auxin (indolebutyric acid-IBA or 2,4-dichlorophenoxyacetic acid - 2,4-D) at one of four concentrations $(0,1000$, 2000 , and $3000 \mathrm{mg} \cdot \mathrm{L}^{-1}$ ), in a $3 \times 2 \times 4$ factorial scheme in a completely randomized design with three replicates of ten cuttings per plot.

The IBA and 2,4-D solutions were prepared by the dilution of the powdered product with $\mathrm{NaOH} 0.5 \mathrm{~N}$ and then adding distilled water to reach a final volume of $1 \mathrm{~L}$. The treatments were applied by submerging 5 $\mathrm{cm}$ of the base of the cuttings in the auxin solution for 5 seconds. Before the application of the treatments, 3 $\mathrm{mm}$ were cut from the end of the cuttings to eliminate the oxidation of the phenolic compounds in this previously exposed region. For the treatment with 0 $\mathrm{mg} \cdot \mathrm{L}^{-1}$ (control), cuttings were submerged in distilled water. After the treatment applications, cuttings were planted in the field in a $15 \mathrm{~m} \times 1.2 \mathrm{~m}$ area under shade cloth (50\% shade). The cuttings were spaced $12 \mathrm{~cm}$ apart within rows and with rows $20 \mathrm{~cm}$ apart, and half of each cutting was buried in the ground. During the development period of the cuttings, they were irrigated twice a day except during rainfall periods.

After 56 days, cuttings were evaluated by determining the percentages of cuttings that had rooted, sprouted, calloused, or died and the average number of roots and root length of the rooted cuttings. Statistical analyses were made using an analysis of variance of the observed data, applying the Tukey test for the comparison of means at a significance level of 5\%. A polynomial regression was applied to evaluate the effect of the auxin concentrations according to the obtained estimates by equations $\left(R^{2} \geq 0.80\right)$.

\section{RESULTS AND DISCUSSION}

Only for the percentages of sprouted and dead cuttings were no significant effects observed among cultivars, while the other parameters presented significant differences. IBA promoted higher rooting than 2,4-D for all rootstocks (Table 1). Probably, these results can be explained by the fact that IBA is considered less toxic at high concentrations and has photostability and microbiological stability (OLIVEIRA et al., 2010; OHLAND et al., 2009; CHAGAS et al., 2008). Moreover, the herbicidal effect of 2,4-D, even when applied only to the base of the cuttings, could harm the vital functions of the cuttings, because auxins can induce prejudicial metabolic and biochemical changes, such as in nucleic acids, the plasticity of the cell wall, and the action of the RNA-polymerase enzyme, and, consequently, in the synthesis of nucleic acids and proteins, and can also induce high cell proliferation in tissues, causing stem epinasty and phloem interruption (OLIVEIRA JÚNIOR et al., 2011).

For the rootstocks evaluated, the cuttings not treated with auxins, on average, had $>86.7 \%$ rooting (Figure 1), indicating that these cutting rootstock cultivars had good rooting capacity without plant hormonal treatment, probably due to their tissue composition, explained by the hormonal balance (ideal levels of intrinsic auxins). The results also showed that 2,4-D did not promote the formation of adventitious roots or sprouting. However, it promoted cutting mortality, which was attributed to its stimulation of ethylene biosynthesis, causing senescence in many tissues. There was a decrease in the percentage of rooted cuttings with increasing auxin concentration, especially for 'IAC-766', and the drop was found up to a concentration of $2,305.6 \mathrm{mg} \cdot \mathrm{L}^{-1}$ (Figure 1), probably due to the prejudicial effect of the cutting treatments with higher auxin concentrations.

Pimenta et al. (2007) studied the rooting of Lippia species cuttings submitted to treatments of 24 hours with $\operatorname{IBA}\left(0,15,30,60\right.$, and $\left.90 \mathrm{mg} \cdot \mathrm{L}^{-1}\right)$, NAA, or $2,4-\mathrm{D}\left(0,17,34,51\right.$ and $\left.68 \mathrm{mg} \cdot \mathrm{L}^{-1}\right)$ and found that 2,4-D did not promote the formation of adventitious roots and that $100 \%$ of the treated cuttings died, which was attributed to the stimulation of ethylene biosynthesis causing senescence in many tissues. On the other hand, Ferreira and Ferrari (2010) obtained an average rooting close to $90 \%$ in atemoya cuttings (Annona cherimola Mill. $\times$ A. squamosa L.) treated with IBA and 2,4-D at concentrations of $0,500,1000,2000,3000,4000$, and $5000 \mathrm{mg} \cdot \mathrm{L}^{-1}$ for 5 seconds.

The herbicidal effect of 2,4-D is highlighted in Figures 2, 3, and 4, which show the effect of using this auxin on the percentages of rooting and sprouting cuttings, number of roots, and length of roots, respectively. It can be seen that when the concentration of the substance increased, the estimated values decreased except for the percentage of dead cuttings. For IBA, the results showed increasing values when 
the concentration increased (Figure 3).

Woodward and Bartel (2005), in a review paper about regulation, action, and auxin interactions, observed that 2,4-D, unlike the other synthetic substances IBA and NAA, inhibited root formation in seedlings of Arabidopsis thaliana at concentrations higher than $0.023 \mathrm{mg} \cdot \mathrm{L}^{-1}$ in a medium culture.

The negative effects of 2,4-D on the percentages of rooted, sprouted, and dead cuttings of different vine rootstocks can be observed in Figure 2; however, for IBA the effects were not significant since the control treatment had higher values of these parameters and the results were similar. It is also important to note the good result of the control for rooted cuttings, indicating that they contained enough auxin levels to stimulate the rooting process and that the exogenous application of 2,4-D was prejudicial, resulting in an herbicidal effect.

Moura-Costa and Lundoh (1994) treated Dryobalanops lanceolata cuttings with 2,4-D in concentrations of 2000,8000 , and $30000 \mathrm{mg} \cdot \mathrm{L}^{-1}$ and observed a reduced rooting percentage with an increasing concentration that they attributed to the phytotoxic effect of this powerful auxin when applied in high concentrations creating an herbicidal effect.

The fast treatment of cuttings with diluted 2,4-D solutions (less concentrated) could probably promote the rooting of cuttings, but this was not true at high concentrations (Figure 2) because of their herbicidal effect.

Even though IBA best promoted rooting in the rootstock cuttings, 2,4-D raised rooting percentages to above $50 \%$ for the cultivars IAC-572 and Paulsen 1103 (Table 1). This suggests that the use of 2,4-D at less concentrated solutions on cuttings of cultivars and species with weaker root formation could improve results. Karimi et al. (2012) found different rooting responses among cultivars to IBA treatment in pomegranate cuttings (Punica granatum L.), and they attributed this to differences in the endogenous auxin concentration in the cultivars.

Sprouted cuttings were exactly the same as the rooted cuttings, and this can be confirmed by the similar percentages of sprouted and rooted cuttings (Table 1). One different result was that the exogenous auxins did not have any significant effects on the percentage of sprouted cuttings from 'IAC-572' rootstock (Table 1). Many authors observed that IBA can supplement the rooting of cuttings but the same could not happening with the sprouting of the cuttings, that can explain the fact that the 'IAC-572' had obtained $80.8 \%$ of rooting and $75.0 \%$ of sprouting, and this reduction was sufficient to equal the results of sprouting of this rootstock for the treatments with 2,4-D $(60.3 \%)$ and IBA (75.0\%) (SOUZA et al., 2012; VIGNOLO et al., 2012;
FERREIRA; FERRARI, 2010).

The regression analysis of the percentage of sprouted cuttings of the vine rootstocks revealed general similarity between this parameter and the percentage of rooted cuttings (Figures 1 and 5). This is because most of the cuttings that rooted also sprouted.

Cuttings of the rootstock 'IAC-766' had high mortality when they were treated with 2,4-D (Table 1). This treatment also had lower percentages of rooted and sprouted cuttings, since the dead cuttings were exactly those that did not root or sprout. The percentage of dead cuttings also increased with increasing auxin concentration (Figure 6), reaching a maximum mortality at a concentration of $2009.2 \mathrm{mg} \cdot \mathrm{L}^{-1}$ of auxins.

The rootstocks 'IAC-766' and 'Paulsen 1103' produced more roots than 'IAC-572' when the cuttings were treated with IBA (Table 1). The number of roots in cuttings is an important factor to determine the propagation capacity of cuttings and the quality of the plants (HARTMANN et al., 2010). The fact that IBA promoted more roots in 'IAC-766' and 'Paulsen 1103' can be related to the increases in rooted cuttings of $8.3 \%$ and $4.2 \%$, respectively, compared to 'IAC-572', which was sufficient to statistically distinguish among the rootstocks in the number of roots in rooted cuttings.

Figure 3 shows the same prejudicial effect of 2,4-D concentrations on the number of roots, while IBA increased the number of roots. These results can be attributed to an increase in the surface area from which to emit roots and the rooting from the base and in all surfaces of the cuttings treated with IBA.

The rootstock 'IAC-572' had more roots in rooted cuttings up to an auxin concentration of $1,834.5$ $\mathrm{mg} \cdot \mathrm{L}^{-1}$ (Figure 7); above this concentration, the probable phytotoxic effect of the auxins was prejudicial to promoting greater root formation.

IBA treatment yielded the greatest root length for all rootstocks, and no differences among them were observed (Table 1). The effect of the auxin concentration was similar to the results for the percentage of rooted cuttings (Figures 1 and 4), following the same reasoning as discussed before for the number of roots.

Ferreira and Ferrari (2010) found decreasing rooting and root length in atemoya cuttings treated with $2,4-\mathrm{D}$ in treatments of $0,500,1000,2000,3000,4000$, or $5000 \mathrm{mg} \cdot \mathrm{L}^{-1}$ (for 5 seconds), and $0,50,100,200$, 300,400 , and $500 \mathrm{mg} \cdot \mathrm{L}^{-1}$ (for $24 \mathrm{~h}$ ), agreeing with the present study. On the other hand, these same authors also demonstrated that IBA decreased rooting and root length in atemoya cuttings.

The regression analysis showed that, for each rootstock, the auxins also reduced root length with increasing concentrations, except for the rootstock 'IAC-766', which showed an increase in root length with concentrations above $1,670.5 \mathrm{mg} \cdot \mathrm{L}^{-1}$ (Figure 8). 
TABLE 1 - Characteristics evaluated in vine roorstock cuttings treated with 2,4-dichlorophenoxyacetic acid $(2,4-D)$ and indolebutyric acid (IBA) $)^{(1)}$.

\begin{tabular}{ccc}
\hline Cultivar & \multicolumn{2}{c}{ Auxins } \\
\cline { 2 - 3 } & $2,4-\mathrm{D}$ IBA \\
\hline \multicolumn{3}{c}{ Rooting (\%) } \\
\hline IAC-572 & $62.5 \mathrm{aB}$ & $80.8 \mathrm{aA}$ \\
IAC-766 & $34.2 \mathrm{bB}$ & $87.5 \mathrm{aA}$ \\
Paulsen 1103 & $56.7 \mathrm{aB}$ & $84.2 \mathrm{aA}$ \\
\hline \multicolumn{3}{c}{ Sprouting (\%) } \\
\hline IAC-572 & $60.3 \mathrm{aA}$ & $75.0 \mathrm{aA}$ \\
IAC-766 & $35.0 \mathrm{bB}$ & $86.7 \mathrm{aA}$ \\
Paulsen 1103 & $50.8 \mathrm{abB}$ & $80.8 \mathrm{aA}$ \\
\hline \multicolumn{3}{c}{ Mortality $(\%)$} \\
\hline IAC-572 & $37.5 \mathrm{bA}$ \\
IAC-766 & $60.8 \mathrm{aA}$ & $19.2 \mathrm{aB}$ \\
Paulsen 1103 & $43.3 \mathrm{bA}$ & $11.7 \mathrm{aB}$ \\
\hline \multicolumn{3}{c}{ Number of roots } \\
\hline IAC-572 & $6.1 \mathrm{aA}$ \\
IAC-766 & $3.3 \mathrm{aB}$ \\
Paulsen 1103 & $8.0 \mathrm{aB}$ & $16.9 \mathrm{bA}$ \\
\hline \multicolumn{3}{c}{ Length of roots (cm) } \\
\hline IAC-572 & $9.7 \mathrm{aB}$ \\
IAC-766 & $5.1 \mathrm{bB}$ & $13.6 \mathrm{aA}$ \\
Paulsen 1103 & $7.4 \mathrm{abB}$ & $13.5 \mathrm{aA}$ \\
\hline
\end{tabular}

(1) Means followed by similar letters, lowercase in the same columns and uppercase in the line, are similar by a Tukey test at a $5 \%$ probability level. Means of the auxin concentrations.

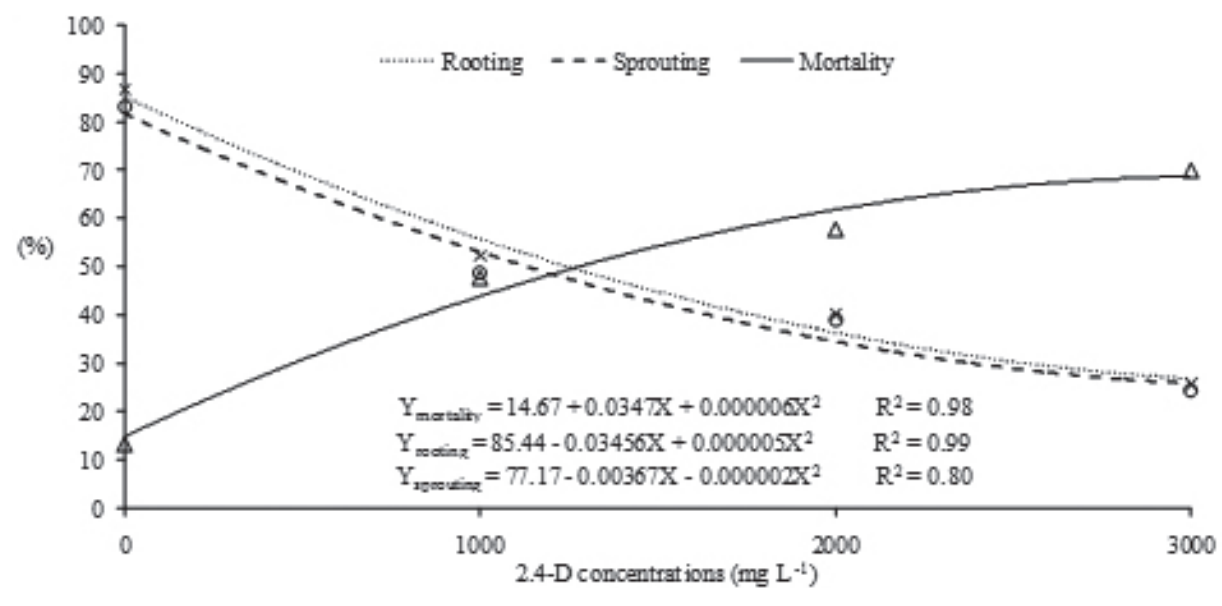

FIGURE 1 - Percentages of rooting, sprouting, and mortality of vine cuttings treated with different concentrations of 2,4-dichlorophenoxyacetic acid (2,4-D). Means of the rootstocks. 


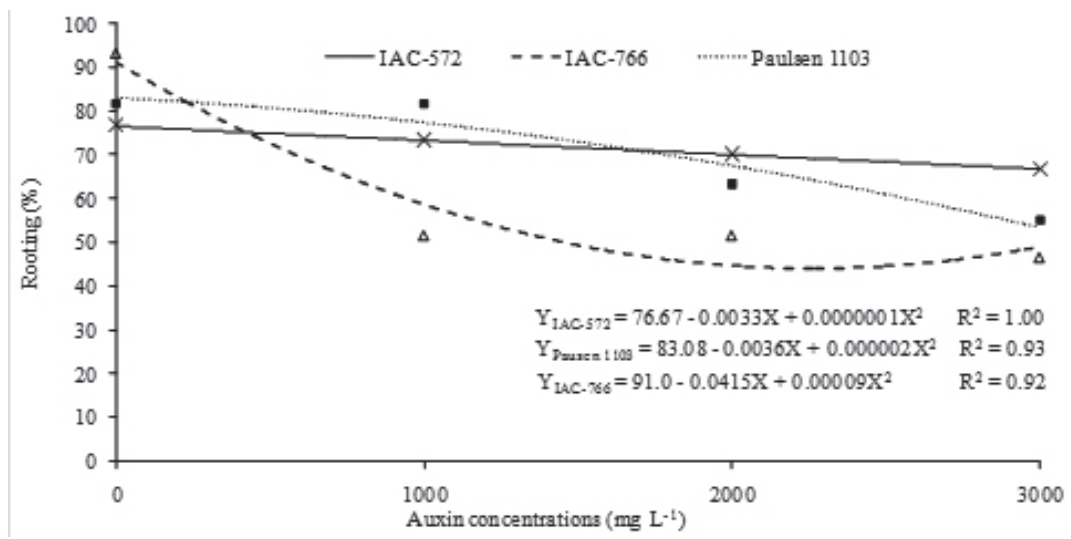

FIGURE 2 - Rooting of the vine rootstock cuttings treated with different auxin concentrations. Means of the auxins.

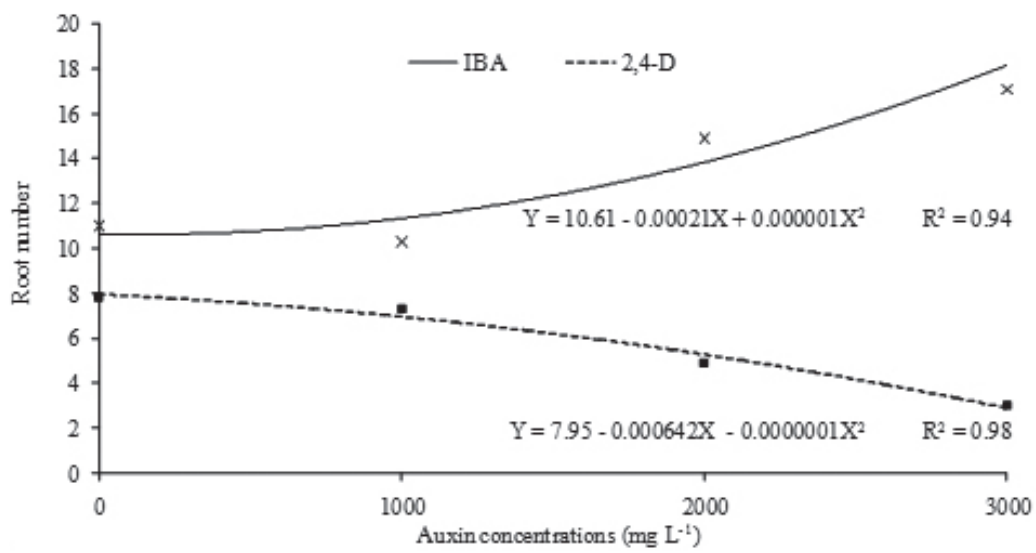

FIGURE 3 - Average number of roots of the rooted vine cuttings treated with different concentrations of 2,4-dichlorophenoxyacetic acid (2,4-D) and indolebutyric acid (IBA). Means of the rootstocks.

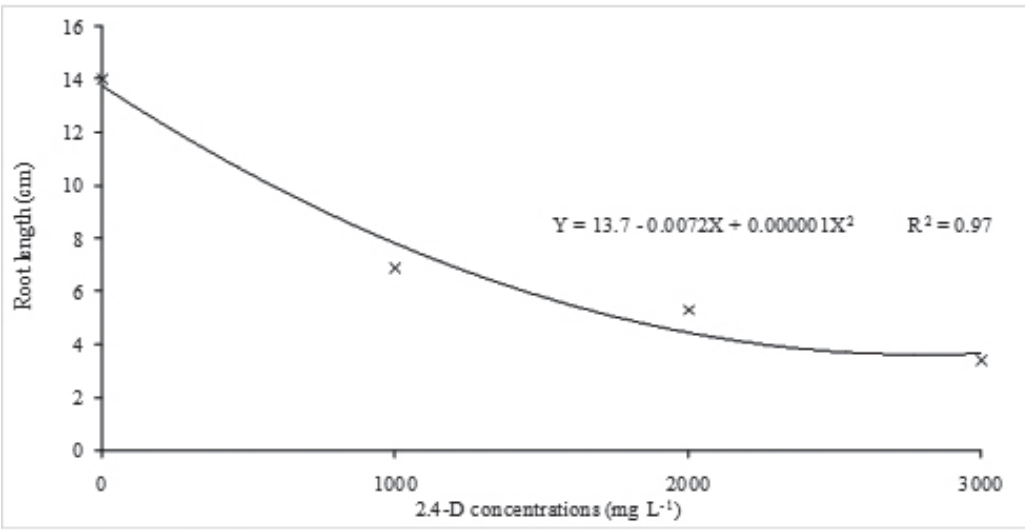

FIGURE 4 - Average length of roots of the rooted vine cuttings treated with different concentrations of 2,4-dichlorophenoxyacetic acid (2,4-D). Means of the rootstocks. 


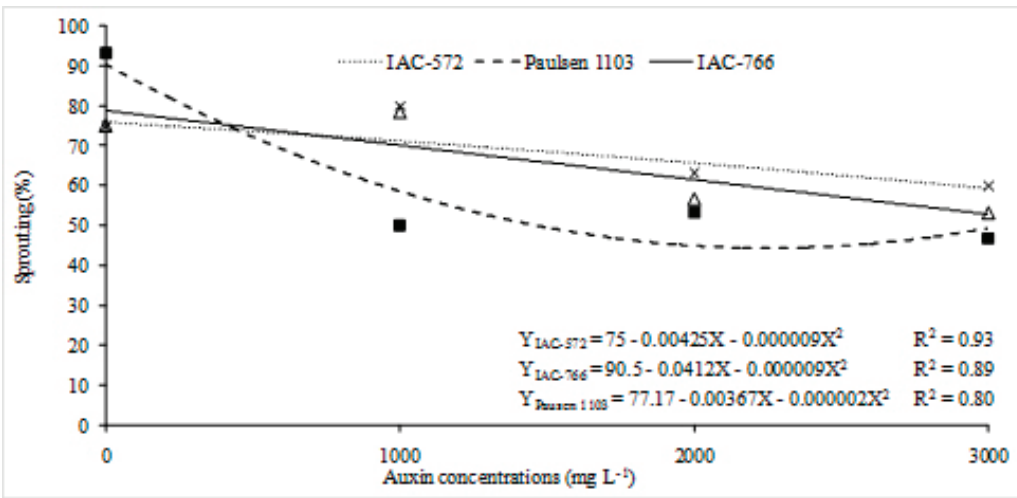

FIGURE 5-Percentage of sprouting cuttings of vines treated with different concentrations of 2,4-dichlorophenoxyacetic acid (2,4-D). Means of the rootstocks.

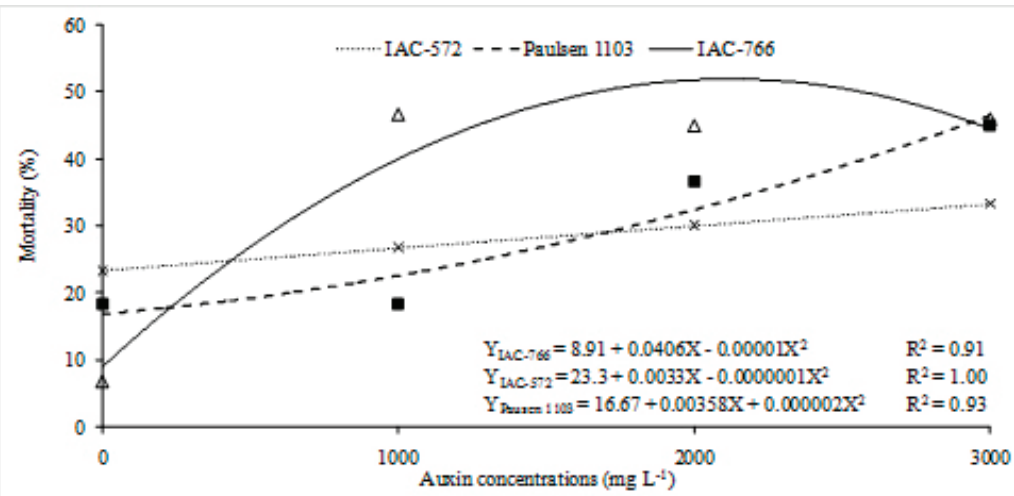

FIGURE 6-Mortality of the vine rootstock cuttings treated with different auxin concentrations. Means of the auxins.

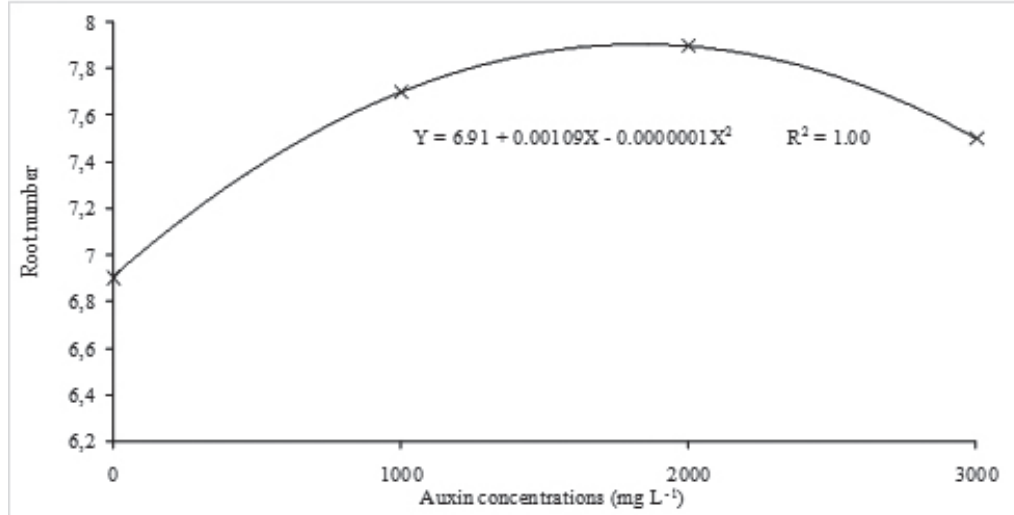

FIGURE 7-Average number of roots of the rooted vine cuttings of 'IAC-572' treated with different concentrations of auxins. Means of the auxins. 


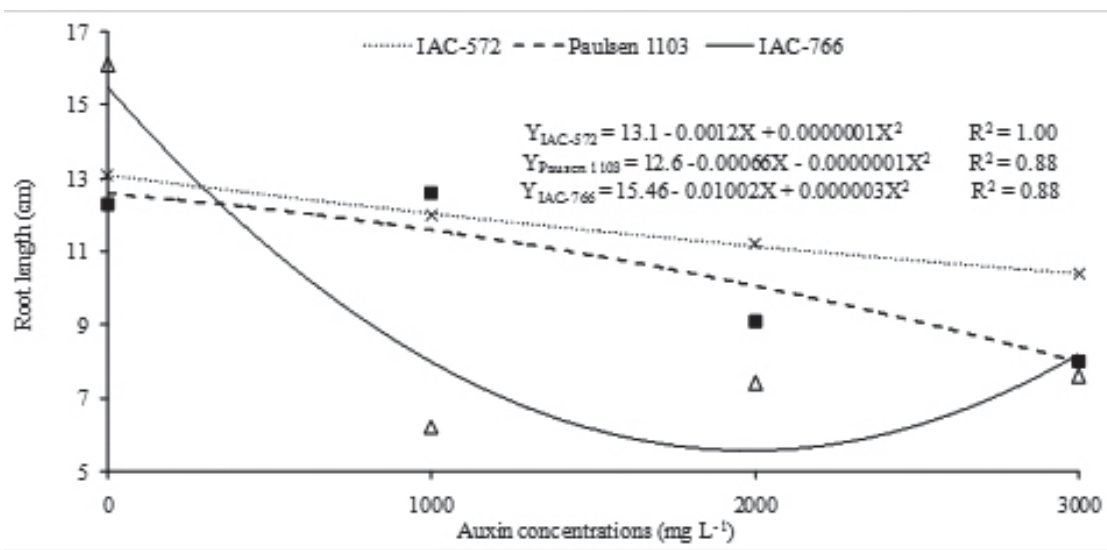

FIGURE 8 - Average length of roots of the rooted vine rootstock cuttings treated with different concentrations of auxins. Means of the auxins.

\section{CONCLUSION}

IBA was more efficient than $2,4-\mathrm{D}$ in promoting the rooting of vine rootstock cuttings in the northeastern Brazil.

The application of 2,4-D in high concentrations decreased the rooting index of vine rootstocks.

Rootstock cuttings easily rooted and did not respond to exogenous treatment with auxins.

The rootstocks 'IAC-572', 'IAC-766', and Paulsen 1103' showed high potential to be used for propagation by cuttings without the use of plant growth regulator treatment with auxins in northeastern Brazil.

\section{REFERENCES}

ALBUQUERQUE, J.A.S. de; ALBUQUERQUE, T.C.S. de. Método para enraizamento de estacas de videira na região do submédio São Franscisco. Petrolina: Embrapa/Cpatsa, 1981. 8p. (Circular Técnica, 2).

CAMPAGNOLO, M.A.; PIO, R. Enraizamento de estacas caulinares e radiculares de cultivares de amoreira-preta coletadas em diferentes épocas, armazenadas a frio e tratadas com AIB. Ciência Rural, Santa Maria, v.42, n.2, p.232-237, 2012.

CHAGAS, E.A.; PIO, R.; NETO, J.E.B.; SOBIERAJSKI, G. da R.; DALL'ORTO, F.A.C.; SIGNORINI, G. Enraizamento de estacas lenhosas de pessegueiro e clones de umezeiros submetidos à aplicação de AIB. Ciência e Agrotecnologia, Lavras, v.32, n.3, p.986-991, 2008.
DENEGA, S.; BIASI, L.A.; ZANETTE, F.; NASCIMENTO, I.R. do; BLASKEVICZ, S.J. Enraizamento de estacas de nove cultivares de Vitis rotundifolia na primavera e verão tratadas com ácido indolbutírico. Scientia Agraria, Curitiba, v.10, n.3, p.199-207, 2009.

FERREIRA, G.; FERRARI, T.B. Enraizamento de estacas de atemoieira (Annona Cherimola Mill. x A. squamosa $\mathrm{L}$.) cv. Gefner submetidas a tratamento lento e rápido com auxinas. Ciência e Agrotecnologia, Lavras, v.34, p.329-336, 2010.

HARTMANN, H.T.; KESTER, D.E.; DAVIES JR., F.T.; GENEVE, R.L. Plant propagation: principles and practices. 8th - ed. New Jersey: Prentice-Hall, 2010.915p.

IBGE - Instituto Brasileiro de Geografia e Estatística. Sistema IBGE de recuperação automática - Sidra. Disponível em: $<$ http://www.sidra.ibge.gov.br $>$. Acesso em: 06 may 2013.

KARIMI,H.R.;AFZALIFAR, M.;ZAREMANSOURI, $M$. The effect of iba and salicylic acid on rooting and vegetative parameters of pomegranate cuttings. International Journal of Agriculture: Research and Review, Ardabil, v.2, p.1085-1091, 2012. Suplemento.

LEÃO, P.C.S.; SOARES, J.M.; RODRIGUES, B.L. Principais cultivares. In: SOARES, J.M.; LEÃO, P.C.S. (Ed.). A viticultura no semiárido brasileiro. Brasília: Embrapa Informação Tecnológica, 2009. p.151-214. 
LONE, A.B.; LÓPEZ, E.L.; ROVARIS, S.R.S.; KLESENER, D.F.; HIGASHIBARA, L.; ATAÍDE, L.T.; ROBERTO, S.R. Efeito do AIB no enraizamento de estacas herbáceas do porta-enxerto de videira VR 43-43 em diferentes substratos. Semina: Ciências Agrárias, Londrina, v.31, n.3, p.599-604, 2010.

MAPA - Ministério da Agricultura, Pecuária e Abastecimento. Sistema de agrotóxicos fitossanitários - Agrofit. Disponível em: <http://agrofit.agricultura. gov.br/agrofit_cons/principal_agrofit_cons $>$. Acesso em: 06 maio 2013.

MOURA-COSTA, P.H.; LUNDO, L. The effects of auxins (IBA, NAA and 2,4-D) on rooting of Dryobalanops lanceolata (Kapur - Dipterocarpaceae) cuttings. Journal of Tropical Forest Science, Kuala Lumpur, v.7, n.2, p.388-340, 1994.

OHLAND, T.; PIO, R.; CHAGAS, E.A.; BARBOSA, W.; KOTZ, T.E.; DANELUZ, S. Enraizamento de estacas apicais de figueira 'roxo de valinhos' em função de época de coleta e AIB. Ciência e Agrotecnologia, Lavras, v.33, n.1, p.74-78, 2009.

OLIVEIRA, A.F.; VIERA NETO, J.; PIO, R.; OLIVEIRA, A.F. de; RAMOS, J.D. Enraizamento de estacas semilenhosas de oliveira sob efeito de diferentes épocas, substratos e concentrações de ácido indolbutírico. Ciência e Agrotecnologia, Lavras, v.34, n.1, p.117-125, 2010.

OLIVEIRA JÚNIOR, R.S. de; CONSTANTIN, J.; INOUE, M.H. Biologia e manejo de plantas daninhas. (Ed.). Curitiba: Omnipax, 2011.348p.
PEÑA, M.L.P.; GUBERT, C.; TAGLIANI, M.C.; BUENO, P.M.C.; BIASI, L.A. Concentrações e formas de aplicação do ácido indolbutírico na propagação por estaquia dos mirtileiros cvs. Flórida e Clímax. Semina: Ciências Agrárias, Londrina, v.33, n.1, p.57-64, 2012.

PIMENTA, M.R.; FERNANDES, L.S.; PEREIRA, U.J.; GARCIA, L.S.; LEAL, S.R.; LEITÃO, S.G.; SALIMENA, F.R.G.; VICCINI, L.F.; PEIXOTO, P.H.P. Floração, germinação e estaquia em espécies de Lippia L. (Verbenaceae). Revista Brasileira de Botânica, São Paulo, v.30, n.2, p.211-220, 2007.

SIMON, S.; PETRÁSEK, J. Why plants need more than one type of auxin. Plant Science, Limerick, v.180, p.454-460, 2011.

SMART, D.R.; KOCSIS, L.; WALKER, M.A.; STOCKERT, C. Dormant buds and adventitious root formation by Vitis and other woody plants. Journal of Plant Growth Regulation, New York, v.21, p.296314, 2003.

SOUZA, E.R.; RIBEIRO, V.G.; MENDONÇA, O.R. de; SANTOS, A. da S.; SANTOS, M.A.C. dos. Comprimentos de estacas e AIB na formação de portaenxertos de videira 'Harmony' e 'Campinas'. Revista Brasileira de Tecnologia Aplicada nas Ciências Agrárias, Guarapuava, v.5, n.2, p.19-32, 2012.

VIGNOLO, G.K.; FISCHER, D.L. de O.; ARAUJO, V.F.; KUNDE, R.J.; ANTUNES, L.E.C. Enraizamento de estacas lenhosas de três cultivares de mirtileiro com diferentes concentrações de AIB. Ciência Rural, Santa Maria, v.42, n.5, p.795-800, May 2012.

WOODWARD, A.W.; BARTEL, B. Auxin: regulation, action, and interaction. Annals of Botany, London, v.95, p.707-735, 2005. 